\title{
https://doi.org/10.46813/2021-136-139 \\ IMPROVEMENT OF HELIUM IONS BEAM FORMATION AND TRANSPORT SYSTEM
}

\author{
A.F. Dyachenko, S.N. Dubniuk, O.V. Manuilenko, S.S. Tishkin \\ National Science Center "Kharkov Institute of Physics and Technology”, Kharkiv, Ukraine \\ E-mail: dyachenkoa@kipt.kharkov.ua
}

\begin{abstract}
Works on improvement of a beam formation and transport system from an accelerating section output to the target complex on NSC KIPT helium ions linear accelerator with output energy of $4 \mathrm{MeV}$, used for carrying out of radiating researches are continued. Results of researches spent with electromagnetic quadrupole lenses, forming a triplet are presented. Experiments with injected $(120 \mathrm{keV})$ and accelerated (4 MeV) helium ions beams by means of advanced beam formation and transport system to a target are continued. The proposal on decrease in thermal loading of a triplet is formulated.
\end{abstract}

PACS: 29.17.w, 29.27.Bd

\section{INTRODUCTION}

Experiments on the new section intended for $\mathrm{He}^{+}$ $(\mathrm{A} / \mathrm{q}=4)$ ions acceleration with $120 \mathrm{keV}$ injection energy and $4 \mathrm{MeV}$ output energy proceed. This section is used for carrying out of applied researches with output energy of $4 \mathrm{MeV}$ (helium ions linear accelerator). Its basic elements are: an injector, resonator with an accelerating structure, placed in a vacuum tank (Fig. 1), and beam formation and transport system from an accelerating section exit to the target chamber with accompanying diagnostic devices for carrying out of radiating researches (Fig. 2) [1]. A special feature of the accelerating structure section is a use of an alternating-phase focusing variant with step-by-step change in a synchronous phase and increasing radio-frequency field amplitude in accelerating gaps on a grouping part of an accelerating-focusing tract [2 - 4].

Originally chosen variant $(a)$ of a beam formation and transport system from an accelerating section output to the target chamber represented a triplet consisting of one long quadrupole lens and two short lenses on each side (see Fig. 2). This variant has given the chance to solve a problem of a beam current density increase, but did not allow long time working.

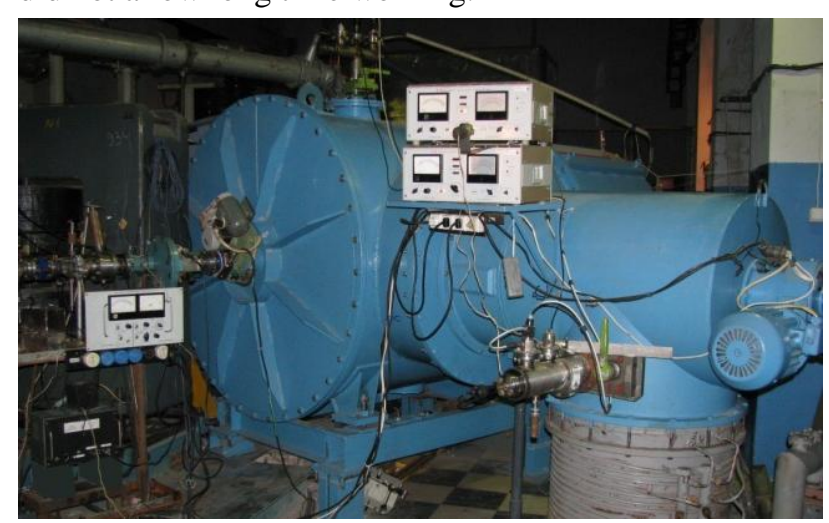

Fig. 1. Helium ions linear accelerator with output energy $4 \mathrm{MeV}$

The work purpose is carrying out numerical and experimental researches of various variants of formation and transport system improvement of helium ions accelerated beam with minimum losses and maximum beam density to a target complex intended for a performance of radiating researches at a long irradiation of samples.

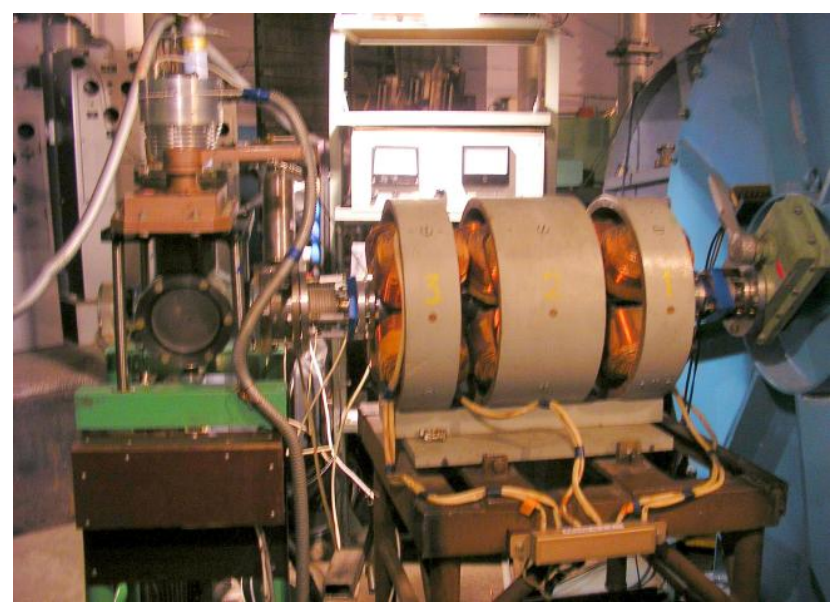

Fig. 2. Initial variant (a) of a beam formation and transport system from an accelerating section output (on the right) to the target chamber (on the left)

\section{PROBLEM STATEMENT}

The conducted researches of triplet quadrupole lenses, and also parameters injected (energy of $120 \mathrm{keV}$ ) and accelerated (energy of $4 \mathrm{MeV}$ ) helium ions beams have shown that the offered of beam formation and transport system on helium ions accelerator output allows to considerably increase of a beam current density on a target and approach to as much as possible value (at the existing equipment) (in detail described in paper [1]). But there was a problem of a thermal mode of quadrupole lenses long time working. The optimum mode on of a beam current density was reached at considerable values of power supplies quadrupole lenses currents (to $10 \mathrm{~A}$ ). It demanded application of their cooling (for example, air).

The beam transport line between sections PSS-15 and BS-5 consisting of 3 triplets and a doublet which has successfully worked some number years, did not demand any cooling as currents values of power supplies on the majority of lenses (8) were to $2 \mathrm{~A}$ and only on last triplet (on a beam course) were to $6 \mathrm{~A}$.

Therefore there was a problem of carrying out numerical and experimental researches of various variants of formation and transport system improvement of helium ions accelerated beam to provide of an accelerator long work mode. 


\section{CALCULATION OF THE TRIPLET FOCUSING CHANNEL}

For performance of an assigned task the decision to use available equipment, i. e. other two similar triplets is accepted. It is offered to replace gradually two extreme short quadrupole lenses on two long (variants $b$ and $c$ ).

For calculation of the transport channel with a focusing triplet and particles dynamics in it beam settlement characteristics on output of applied accelerating structure with an alternating-phase focusing, received by means of code APFRFQ were used: $4 \mathrm{MeV}$ beam energy, $4 \mathrm{~mA}$ beam current, $30 \mathrm{~mm}$ beam diameter, $0 \mathrm{mrad}$ slope angle of beam envelope [5,6]. As a result of calculation and optimization of triplet main parameters: selection of drift intervals lengths and magnetic field gradients in lenses amounts for a transport channel geometry, values of magnetic field gradients in electromagnetic quadrupole lenses have been received and particles dynamics in such channel is calculated.

Beam envelopes (horizontal envelope is a dark blue, continuous line and vertical envelope is red, a dashed line), received for the chosen geometry of the channel (variant $b$ ) by means of code Trace-3d [7] are presented in Fig. 3. By numerals are designated: drift intervals: $1-100 \mathrm{~mm}, 3-75 \mathrm{~mm}, 5-70 \mathrm{~mm}, 7-250 \mathrm{~mm}$; poles electromagnetic quadrupole lenses: 2, $4-180 \mathrm{~mm}$, $6-90 \mathrm{~mm}$. Magnetic field gradients created in quadrupole lenses: $2-(-7.5) \mathrm{T} / \mathrm{m}, 4-(+15.25) \mathrm{T} / \mathrm{m}, 6-(-20) \mathrm{T} / \mathrm{m}$.

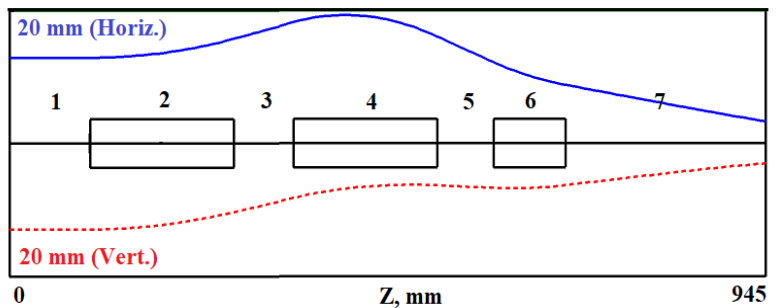

Fig. 3. Calculation results of a transport channel of helium ions beam from an accelerating section output (at the left) to a target (variant $b$ )

Beam envelopes (horizontal envelope is a dark blue, continuous line and vertical envelope is red, a dashed line), received for the chosen geometry of the channel (variant $c$ ) by means of code Trace-3d [7] are presented in Fig. 4.

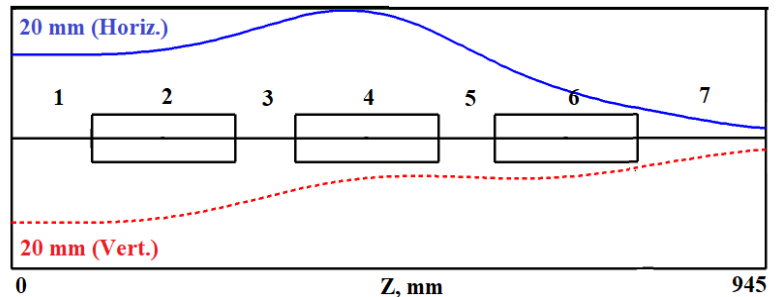

Fig. 4. Calculation results of a transport channel of helium ions beam from an accelerating section output (at the left) to a target (variant c)

By numerals are designated: drift intervals: 1 - $100 \mathrm{~mm}, 3$ - $75 \mathrm{~mm}, 5$ - $70 \mathrm{~mm}, 7$ - $160 \mathrm{~mm}$; poles electromagnetic quadrupole lenses: 2, 4, 6-180 mm. Magnetic field gradients created in quadrupole lenses: $2-(-8) \mathrm{T} / \mathrm{m}, 4-(+16) \mathrm{T} / \mathrm{m}, 6-(-15,1) \mathrm{T} / \mathrm{m}$.
Transfer to variant $c$ allows not only to lower the maximum gradient of a magnetic field in last lens, but also to reduce beam diameter. The settlement results received on idealized model, can several differ from experimental values.

\section{RESEARCH OF THE TRIPLET THERMAL MODE}

Calculation results of a triplet focusing channel for variants $b$ and $c$ were verified in actual conditions.

Variants $b$ and $c$ of a beam formation and transport real system are respectively presented in Figs. 5, 6 .

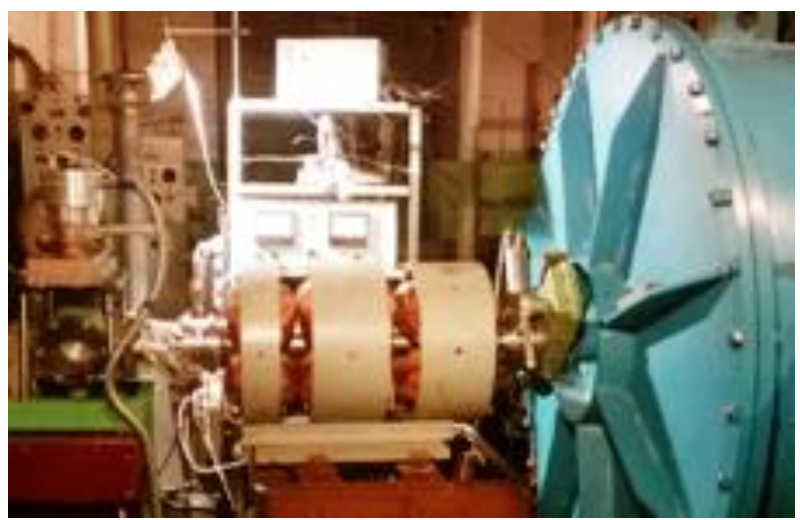

Fig. 5. Variant (b) of a beam formation and transport real system

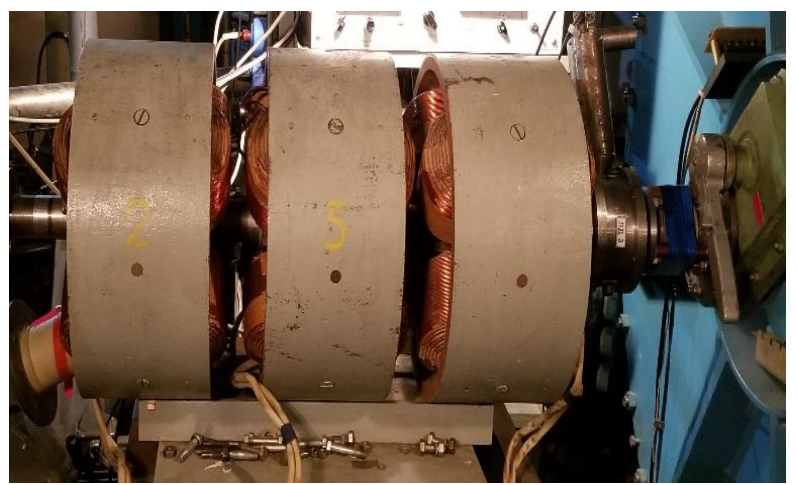

Fig. 6. Variant (c) of a beam formation and transport real system

The spent experimental researches have allowed finding optimum currents on focusing lenses of a triplet in various variants of its execution, at which beam density on a target becomes maximum. As in an initial variant $a$ there are enough great currents values on quadrupole lenses led to their fast warming up - the temperature reached $100^{\circ} \mathrm{C}$, and at a variant $c$ temperature did not exceed $50^{\circ} \mathrm{C}$ at accelerator work in one shift (an order of $6 \mathrm{~h}$ ) that the focusing variant $c$ has been selected (values of currents are resulted in the Table). At longer work of the accelerator last quadrupole lens on a course of a beam demanded air cooling.

Optimum values of currents in lenses

\begin{tabular}{|c|c|c|c|}
\hline Variant & \multicolumn{3}{|c|}{ Current, A } \\
\hline$a: \mathrm{S}+\mathrm{L}+\mathrm{S}$ & 6.6 & 6.7 & 10 \\
\hline$c: \mathrm{L}+\mathrm{L}+\mathrm{L}$ & 3.2 & 5.8 & 5.6 \\
\hline
\end{tabular}

By results of spent experimental researches and calculations the definitive variant $(c)$ of a beam following channel to a target complex is formed. 


\section{PROPOSITION ON DECREASE IN THERMAL LOADING OF THE TRIPLET}

Cardinally to solve a problem of a triplet thermal mode it is possible by transfer to pulse power supplies of quadrupole lenses. It will allow not only it is essential to lower thermal heating of quadrupole lenses coils, but also to reduce power consumption, respectively. This transition will not demand considerable expenditures as there is a possibility to use the available equipment and materials.

The quadrupole lens has 4 current windings which calculated on currents to $10 \mathrm{~A}$. At consecutive connection of windings the general inductance makes $0.6 \mathrm{H}$ and resistance on a direct current $-6 \Omega$. At parallel connection of windings the general inductance makes approximately $0.0375 \mathrm{H}$ and resistance on a direct current $-1.5 \Omega$.

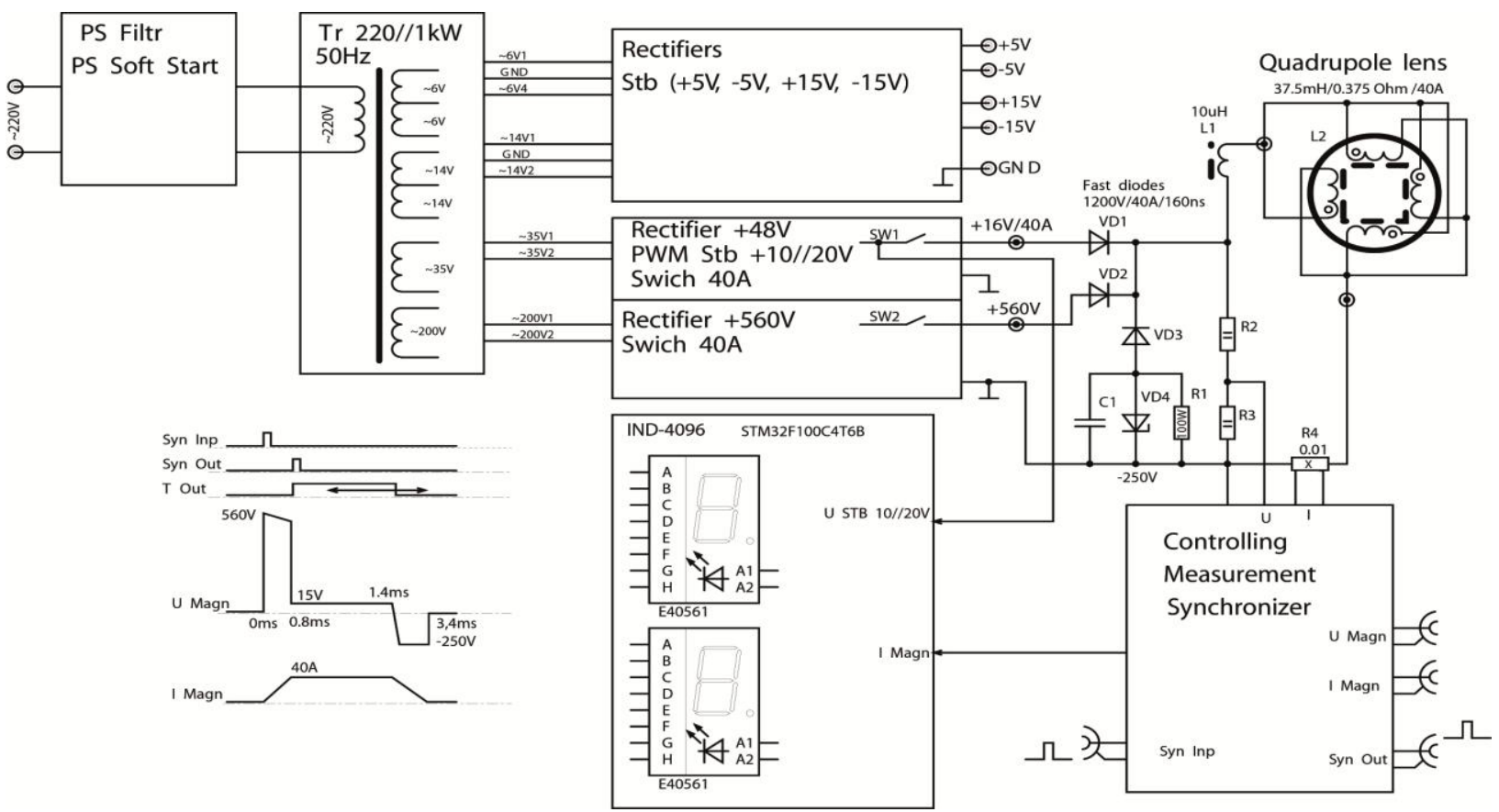

Fig. 7. Function scheme of the quadrupole lens pulse power supply

The module of the rectifier and voltage stabilizer $+16 \mathrm{~V} / 40 \mathrm{~A}$ is intended for a power by the stabilized current of quadrupole lens during an impulse of the accelerator work (from 100 to $1000 \mu \mathrm{s}$ ). The stabilizer is realized under the scheme of pulse-width modulation (PWM) with high efficiency. On a stabilizer output there is a power key with possibility of switching-off from loading.

The module of the rectifier $+560 \mathrm{~V} / 40 \mathrm{~A}$ is intended for initial fast riding up of a quadrupole lens power current (from 0.5 to $2 \mu \mathrm{s}$ ). The rectifier is realized under the voltage doubler scheme with accumulative condensers charging to $+560 \mathrm{~V}$ and a power key with possibility of switching-off from loading. The condensers capacity of a voltage doubler is chose from level $5 \%$ of voltage droop during initial fast riding up of a quadrupole lens power current. The riding up voltage value is selected from a condition of the winding electric strength from lens keeper and the maximum breakdown voltages of power output keys (it is recommended
The function scheme consists of 7 modules (Fig. 7). Schemes modeling of quadrupole lens initial excitation were made in program Micro-Cap 9. The module of the entrance power filter <PS Filtr > is intended for protection of all block against pulse hindrances at work of the charged particles accelerator. Also in it soft start function <PS Soft Start> for power transformer inclusion is realized at initial charging of all power rectifiers condensers.

The transformer has a primary winding on $\sim 220 \mathrm{~V}$ and 6 secondary windings for all block power $(2 * \sim 6 \mathrm{~V}$, $\left.2^{*} \sim 14 \mathrm{~V}, \sim 36 \mathrm{~V}, \sim 200 \mathrm{~V}\right)$. The general pulse capacity can reach to $1000 \mathrm{~W}$.

The module of rectifiers and voltage stabilizers $+/-5 \mathrm{~V},+/-15 \mathrm{~V}$ are intended in order to receive of power voltages of digital and analogue microcircuits in block management modules. 
use parallel connection of quadrupole lens windings with the general inductance to $37.5 \mathrm{mH}$ and resistance of losses on a direct current $0.375 \Omega$. Thus current riding up time decreases to $800 \mu \mathrm{s}$ (a current $40 \mathrm{~A}$ ). The time current resorption to $5 \%$ at recuperation through diode VD3 and R1, C1, VD4 at stabilitron voltage $250 \mathrm{~V}$ it is possible reduce to $2 \mathrm{~ms}$. At the same time almost all energy which has been saved up in quadrupole lens, will be emitted on external loading and it will reduce heat release in quadrupole.

The quadrupole stable impulse width is chose of accelerator working conditions. Approximately in this impulse middle storing of a lens current and its indication on the additional indicator (the indication module) is made. Also voltage indication on the stabilizer output +16 V/40 A (too with storing in the same time of sample) is made.

To operate the block in regular work on the accelerator it is recommended by means of the microcontroller of STM32 series with communication on an optical cable. Fine tuning of a lens current at warming up of the copper coil is thus possible. Throttles PWM of a regulator should be execute from a multicore wire.

\section{CONCLUSIONS}

Necessary elements are made, the advanced system of formation and transport of helium ions beam from an accelerator output to a target is calculated, developed, collected and adjusted. The conducted researches have shown that the offered system of a beam formation and transport on output of helium ions accelerator allows to essentially increase of a beam current density on a target and approach to as much as possible value (at the existing equipment) for carrying out of experimental researches at a long irradiation of samples. Proposition on decrease in thermal loading of a triplet that will allow to solve cardinally a problem of its thermal mode at long work is formulated.

\section{ACKNOWLEDGEMENTS}

We thank O.A. Turchin for his qualified and fundamental technical support in the development of the quadrupole lens pulse power supply.

\section{REFERENCES}

1. A.F. Dyachenko, S.N. Dubniuk, A.P. Kobets, et al. The bunch formation and transport system to the target of the helium ions linac // Problems of Atomic Science and Technology. Series "Plasma Electronics and New Methods of Acceleration”. 2018, № 4, p. 52-55.

2. V.O. Bomko, O.F. Dyachenko, Ye.V. Ivakhno, et al. New prestripping section of the MILAC linear accelerator designed for accelerating a high current beam of light ions // Proceedings of EPAC 2006 Edinburgh, Scotland. 2006, p. 1627-1629.

3. V.O. Bomko, O.F. Dyachenko, O.M. Yegorov, et al. Development of investigations on the MILAC heavy ion linear accelerator // Proceedings LINAC08, Vancouver, Victoria, Canada. 2008, p. 187-189.

4. V.O. Bomko, A.F. Dyachenko, B.V. Zajtsev, et al. Inductance-capacitor system for tuning of interdigital structure of the ion linear accelerator // Problems of Atomic Science and Technology. Series "Nuclear Physics Investigations”. 2007, № 5, p. 180-183.

5. S.S. Tishkin. Combined focusing by RF-field for ion linac accelerators // The Journal of Kharkiv National University. Physical Series "Nuclei, Particles, Fields”. 2008, № 808, issue 2(38), p. 37-46.

6. A.F. Dyachenko, B.V. Zaytsev, S.S. Tishkin, et al. An accelerating and focusing structure with combined RF focusing for heavy ion accelerator // Problems of Atomic Science and Technology. Series "Nuclear Physics Investigations”. 2014, № 3, p. 16-19.

7. W.P. Lysenko, D.P. Rusthoi, K.C.D. Chan, G.H. Gillespie, and B.W. Hill. TRACE 3-D Code Improvements // Proceedings of the 1996 Computational Accelerator Physics Conference, September 24-27, 1996, Williamsburg, Virginia.

Article received 14.10.2021

\section{УСОВЕРШЕНСТВОВАНИЕ СИСТЕМЫ ФОРМИРОВАНИЯ И ТРАНСПОРТИРОВКИ ПУЧКА ИОНОВ ГЕЛИЯ}

\section{А.Ф. Дьяченко, С.Н. Дубнюк, О.В. Мануйленко, С.С. Тишкин}

Продолжены работы по усовершенствованию системы формирования и транспортировки пучка с выхода ускоряющей секции к мишенному комплексу на линейном ускорителе ионов гелия ННЦ ХФТИ с выходной энергией 4 МэВ, используемого для проведения радиационных исследований. Представлены результаты исследований, проведенных с электромагнитными квадрупольными линзами, образующими триплет. Продолжены эксперименты с инжектируемым (120 кэВ) и ускоренным (4 МэВ) пучками ионов гелия с помощью усовершенствованной системы формирования и транспортировки пучка к мишени.

\section{УДОСКОНАЛЕННЯ СИСТЕМИ ФОРМУВАННЯ ТА ТРАНСПОРТУВАННЯ ПУЧКА ІОНІВ ГЕЛІЮ}

\section{О.Ф. Дьяченко, С.М. Дубнюк, О.В. Мануйленко, С.С. Тінкін}

Продовжено роботи з удосконалення системи формування й транспортування пучка з виходу прискорювальної секції до мішеневого комплексу на лінійному прискорювачі іонів гелію ННЦ ХФТІ з вихідною енергією $4 \mathrm{MeB,} \mathrm{що} \mathrm{використовується} \mathrm{для} \mathrm{проведення} \mathrm{радіаційних} \mathrm{досліджень.} \mathrm{Подано} \mathrm{результати} \mathrm{досліджень,}$ проведених з електромагнітними квадрупольними лінзами, які утворюють триплет. Продовжено експерименти 3 інжектуємим (120 кеВ) і прискореним (4 МеВ) пучками іонів гелію за допомогою удосконаленої системи формування та транспортування пучка до мішені. 